\title{
Gastrointestinal Nursing \\ Knowledge and education to inform evidence-based practice in Gastroenterology Nursing: A scoping review \\ --Manuscript Draft--
}

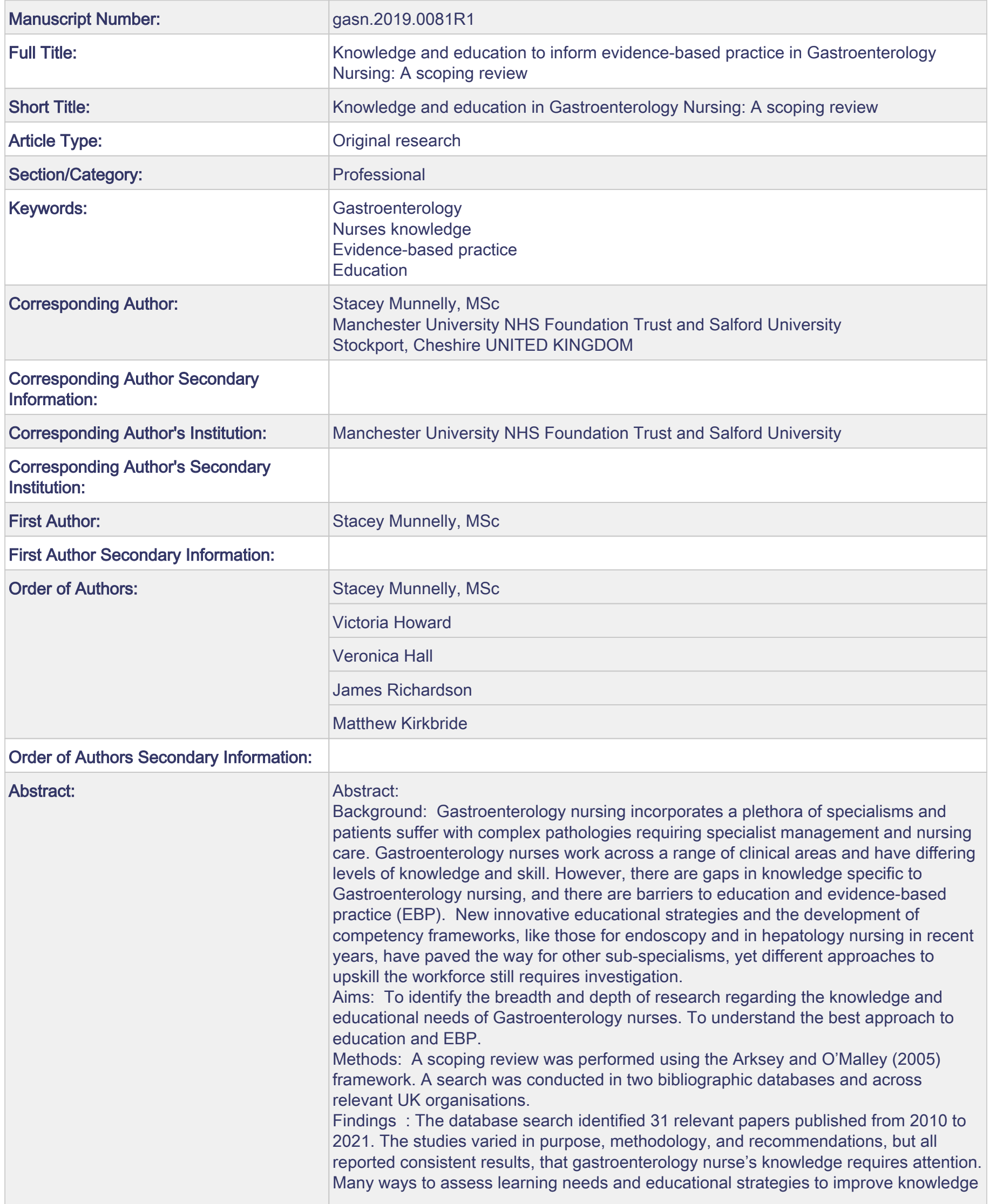


and EBP were proposed.

Conclusion: Gastroenterology nurses' knowledge requires development, to improve both the confidence and clinical practice of nurses, and the experiences and morbidity of patients. The educational and development requirements of Gastroenterology nurses vary across a wide spectrum of needs and draw on a vast range of resources and evidence base. Solutions do not need to be expensive or time consuming and can be practical, utilising existing resources and delivered at local, regional, and national levels. At the same time, to deliver truly EBP nurses must develop the critical analysis skills required to locate, appraise, and organise evidence, interpreting it into the practicalities for decision making. Future researchers should consider exploration of the instruments used to measure EBP and competence of Gastroenterology nurses. To evaluate the effectiveness of different educational models and assist educators in the development and refinement of specialist educational programmes.

\begin{tabular}{|l|l|}
\hline Response to Reviewers: & \\
\hline Additional Information: & \\
\hline Question & Response \\
\hline $\begin{array}{l}\text { Please enter the word count of your } \\
\text { manuscript excluding references and } \\
\text { tables }\end{array}$ & 3846 \\
\hline
\end{tabular}




\section{Short title:}

Knowledge and education to inform evidence-based practice in Gastroenterology Nursing: A scoping review.

\section{Authors:}

Stacey Munnelly, Advanced Nurse Practitioner Gastroenterology and Hepatology Manchester Foundation Trust and Lecturer Practitioner, University of Salford.

S.munnelly1@salford.ac.uk

Victoria Howard, Clinical Nurse Specialist in Inflammatory Bowel Disease, Queen's Medical Centre, Nottingham and Lecturer Practitioner, University of Salford

v.e.howard@salford.ac.uk

Veronica Hall, Consultant Nurse Gastroenterology, The Royal Bolton Foundation Trust, and Lecturer Practitioner, University of Salford.

v.hall@salford.ac.uk

James Richardson Lecturer in Nursing \& Programme Leader for GI Disorders PG

Cert/modules, University of Salford.

J.Richardson3@salford.ac.uk

Matthew Kirkbride Clinical Nurse Specialist in Inflammatory Bowel Disease Manchester Foundation Trust and Lecturer Practitioner, University of Salford.

M.Kirkbride1@salford.ac.uk

Corresponding author: Stacey Munnelly S.munnelly1@salford.ac.uk

stacey.munnelly@mft.nhs.uk

Phone: 07834374906

\section{Abstract:}

Background: Gastroenterology nursing incorporates a plethora of specialisms and patients suffer with complex pathologies requiring specialist management and nursing care.

Gastroenterology nurses work across a range of clinical areas and have differing levels of knowledge and skill. However, there are gaps in knowledge specific to Gastroenterology nursing, and there are barriers to education and evidence-based practice (EBP). New innovative educational strategies and the development of competency frameworks, like those for endoscopy and in hepatology nursing in recent years, have paved the way for 
other sub-specialisms, yet different approaches to upskill the workforce still requires investigation.

Aims: To identify the breadth and depth of research regarding the knowledge and educational needs of Gastroenterology nurses. To understand the best approach to education and EBP.

Methods: A scoping review was performed using the Arksey and O'Malley (2005) framework. A search was conducted in two bibliographic databases and across relevant UK organisations.

Findings: The database search identified 31 relevant papers published from 2010 to 2021. The studies varied in purpose, methodology, and recommendations, but all reported consistent results, that gastroenterology nurse's knowledge requires attention. Many ways to assess learning needs and educational strategies to improve knowledge and EBP were proposed.

Conclusion: Gastroenterology nurses' knowledge requires development, to improve both the confidence and clinical practice of nurses, and the experiences and morbidity of patients. The educational and development requirements of Gastroenterology nurses vary across a wide spectrum of needs and draw on a vast range of resources and evidence base. Solutions do not need to be expensive or time consuming and can be practical, utilising existing resources and delivered at local, regional, and national levels. At the same time, to deliver truly EBP nurses must develop the critical analysis skills required to locate, appraise, and organise evidence, interpreting it into the practicalities for decision making. Future researchers should consider exploration of the instruments used to measure EBP and competence of Gastroenterology nurses. To evaluate the effectiveness of different 
educational models and assist educators in the development and refinement of specialist educational programmes. 


\section{Knowledge and Education to Inform Evidence-based Practice in Gastroenterology Nursing: A}

\section{scoping review.}

\section{Background}

Gastroenterology or Gastrointestinal (GI) Nursing is a distinct specialism. Nurses working in GI services will encounter patients suffering from acute, minor GI disorders to severe life-threatening and chronic illness, requiring highly skilled clinical management, including specialist endoscopy, radiological interventions, and surgery for both benign and malignant diseases (Brotherton, Taylor \& Keeling, 2013, and Norton, 2012). Patients present with complex physical, psychological, and social needs, due to stigma, body image perceptions, unpleasant, embarrassing symptoms, and the chronicity of some pathologies (Haycock, Matharoo \& Thomas-Gibson, 2012, and Joukar, MansourGhanaei, Soati \& Meskinkhoda, 2012). GI nurses work across a range of clinical areas and have differing levels of knowledge and skills. From the junior gastroenterology ward nurse, who following initial training, will be expected to have a broad knowledge of the speciality, including Hepatology, Biliary- Pancreatic and Luminal diseases, to experienced nurses working in specialist roles and at advanced levels. Many of whom complete extended clinical skills training, for example nurse endoscopy, and have elevated their academic study to Master's and Doctoral levels. These nurses provide autonomous, expert management, often to vulnerable and 'difficult to reach' patients (Naghdi et al., 2017, and Norton, 2012). Consequently, the educational, development requirements of gastroenterology nurses vary across a wide spectrum of needs and draw on a vast range of resources and evidence base.

An evidence-based culture is aspired to for optimal patient care in the NHS and is a professional standard of practice for nurses, according to the Nursing \& Midwifery Council, 'The Code' (NMC, 2018a) and 'Standards of Proficiency for registered nurses' (NMC, 2018b). Evidence based practice (EBP) has been defined many times but is collectively agreed that in healthcare it is the integration of best research evidence with clinical expertise and patient values (NHS England, 2017). To gain 
expertise, nurses must develop their professional competence through clinical experience and the acquisition of knowledge; keeping updated on the latest advances in practice, using this knowledge to make decisions regarding the best options for care with their patients. To achieve this, continuous education and reflective practice of the registered nurse is required (Barnwell, 2016 and NMC, 2018b). Processes that are no longer just suggested but mandated by the recent evolution of 'revalidation', whereby nurses are now asked to provide evidence of their continuous professional development to their employers (NMC, 2019 and Taylor, Burch \& Black, 2016).

Research surrounding gastroenterology nurses' knowledge and EBP is not immediately apparent on searching the literature. Therefore, a scoping review method was adopted to examine the breadth and depth of publications and to identify gaps in the research. Scoping reviews are useful to map the extent of research in little focused on areas, differing from systematic reviews, where the purpose is to summarise the best quality research findings on a particular question (Davis, Drey \& Gould 2009, and Pham et al 2014). This can, however, have drawbacks as the potential for bias is greater in scoping reviews. As typically, they do not include a rigorous assessment of quality, instead using studies based on their existence rather than their design and research methodology (Grant \& Booth 2009).

For transparency and replicability, the five-stage methodology proposed by Arksey \& O'Malley (2005) is used to structure the review. In addition, a sixth stage involving consultation with stakeholders to seek feedback on the scoping results as proposed by Levac, Colquhoun \& O’Brien (2010) will offer a deeper understanding of the findings and enrich the knowledge gained through expert input. 


\section{A scoping review}

\section{Stage 1: The research question}

This review was guided by the question, 'What is the knowledge base and educational needs of Gastroenterology nurses that underpins EBP?'.

\section{Stage 2: Identification of relevant studies}

Two databases were searched: British Nursing Index and Medline (Ovid), chosen for their wideranging access to relevant publications. A Boolean search method was applied.

Inclusion and exclusion criteria were set,

- Studies published after January 2010 to capture the most up to date research.

- Peer reviewed, to reduce the risk of bias and increase reliability.

- English language, due to the cost and time of translation

- Full text article access only, due to time constraints.

- Relevant to adult gastroenterology nursing practice.

A total of 1854 results were returned. See table 1.

In addition, reputable UK healthcare affiliated organisations were searched for their contribution to the topic.

\section{Stage 3: Study selection}

The search strategy returned many irrelevant studies, not specific to gastroenterology nursing. A preliminary review of titles with a deeper dive of abstracts was conducted if the search terms were present. The CRAAP test (Meriam Library, 2019) was then applied to evaluate the currency, relevance, authority, accuracy, and purpose of each publication to increase reliability in the sources. 19 duplicate studies were removed and a total of 31 publications were chosen using the inclusion/ exclusion criteria and based on the 'best fit' to the research question in the abstracts. Each paper 
was then read in full to determine its relationship to the topic. Other evidence suggested through stakeholder consultation include publications by The Joint Advisory Group on Gastrointestinal Endoscopy accreditation standards for endoscopy services (JAG 2016) and JETS workforce (JAG, 2019), The Royal College of Nursing; Caring for People with Liver Disease including Liver Transplantation: A Competence Framework for Nursing (RCN 2019), and the Inflammatory Bowel Disease standards (IBD UK, 2019).

\section{Stage 4: charting the data.}

Each study was reviewed to understand the population, aims and research methods, and to extract results by key themes about nursing knowledge, education strategies and EBP. Findings are summarised in table 2 . There are gaps in the data set where the information was not provided or relevant to the research paper.

\section{Stage 5: Collating, summarising, and reporting the results.}

The different types of research include nine descriptive studies, four correlational studies, six quasiexperimental studies, four mixed method studies, five literature reviews, two case studies, one global clinical guideline and four UK clinical guidelines/standards from the stakeholder scope. See table 3.

The main themes identified were;

I. Knowledge base of Gastroenterology Nurses.

II. Educational needs of Gastroenterology Nurses.

III. Solution based approaches to education and EBP.

The results are reported in a literature review. 


\section{Stage 6 (optional): Consultation Exercise}

Davis et al (2009) acknowledge the valuable contribution

that stakeholders can offer to scoping. Feedback on the

relevance and meaning of the search results was taken

from the researchers' peers who are clinical and academic

practitioners in the field of post graduate

Gastroenterology Nursing education. This consultation

provided insight into professional educational experiences

and available resources outside the scope of the database

literature.
Professionals/Stakeholders consulted:

Veronica Hall Consultant Nurse in Gastroenterology, Bolton NHS Foundation Trust \& Lecturer Practitioner, GI Disorders PG Cert/modules, Salford University.

Victoria Howard Inflammatory Bowel Disease Clinical Nurse Specialist, Nottinghamshire Healthcare NHS Foundation Trust \& Associate Lecturer Practitioner Salford University, GI PG Cert/modules.

Matthew Kirkbride Inflammatory Bowel Disease Clinical Nurse Specialist, Manchester NHS Foundation Trust \& Associate Lecturer Practitioner, GI disorders PG Cert/modules, Salford University.

Stacey Munnelly Advanced Nurse Practitioner in Gastroenterology, Manchester NHS Foundation Trust \& Associate Lecturer Practitioner, GI disorders PG Cert/modules, Salford University.

James Richardson Lecturer in Nursing \& Programme Leader for GI Disorders PG Cert/modules, Salford University. 


\section{Literature review}

\section{i) Knowledge base of Gastroenterology Nurses}

Research exploring how gaps in the knowledge of Gastroenterology Nurses can cause barriers to care and detract from patient experience and outcomes is limited. Studies mainly focus on single GI diseases or interventions. However, the available research shows there are common issues affecting the whole patient journey from screening and assessment, through to management of GI disease, and end of life care.

There are a few studies that highlight gaps in knowledge around screening and GI diseases that suggest problems with initial diagnosis. For example, a mixed methods exploration of American nurses' knowledge regarding colorectal cancer (CRC) by Kelly (2015), found nurses rated their knowledge as low and important diagnostic information was omitted from 95\% of their assessments. In a recent cross-sectional survey by Lang et al, (2020), nurse practitioner knowledge of CRC screening guidelines and methods of investigation were variable. Suggesting education on screening guidelines and options is required to improve CRC rates. Similarly, a Canadian descriptive design by Naghdi et al (2017) assessed the knowledge and educational needs of healthcare providers in Hepatitis C using a survey. Finding Nurses lacked confidence in screening, suggesting a need for education to improve underdiagnosis of viral hepatitis and open access to therapy for patients.

Considering management of patients with a GI diagnosis'; research finds that poor knowledge of GI disease and treatments causes low nurse confidence and detracts from safety and patient experience. As gastroenterology nurses work in specialist areas, it is surprising to learn that a multicentre study by Sephton et al., (2013), using the validated Crohn's and Colitis knowledge (CCKNOW) questionnaire to compare UK gastroenterology ward and non-gastroenterology nurses' knowledge of GI tract anatomy and Inflammatory Bowel Disease (IBD), it was concluded that knowledge was, 
overall poor. With little difference between either group, other than gastroenterology nurses had better knowledge of treatments. Suggesting more needs to be done to provide specialist education to gastro ward nurses. This extends to the nursing interventions provided in the speciality. For example, a multi-centre study by Groenkjaer (2015) surveyed 94 nurses and found that knowledge of oral care in liver disease was inadequate, putting patients at risk of developing infection, with nurses citing their initial training as suboptimal. A questionnaire by Embleton \& Henderson (2020), disseminated via social media, demonstrated nurses had a lack of awareness of the need for digital rectal (DRE) when administering rectal medications. Nurses lacked competence and feared performing DRE, citing training as a problem with only $38 \%$ of respondents reporting they had received any formal DRE training. Likewise, in a multi- centre study using convenience sampling that evaluated nurse's risk perception of enteral nutrition (EN), Feng et al (2021) found nurses educational backgrounds influenced EN risk perception. Highlighting the importance of adequate knowledge and training in a potentially dangerous intervention. Furthermore, a UK survey by Aludul et al., (2018) comparing differences in professionals' attitudes and prescribing practices of biosimilar drugs, concluded nurses were less knowledgeable and lacked confidence when compared to their medical and pharmacist colleagues, causing communication issues for patients. But perhaps more concerning, a single centre correlational study by Joukhar et al (2012) performed to understand attitudes of healthcare providers towards patients with Hepatitis $\mathrm{C}$ infection, demonstrated that negative stigmatised attitudes were more likely to be conveyed by staff whose knowledge regarding viral hepatitis was weak, and more knowledgeable staff were more likely to show positive attitudes towards patients. Demonstrating a significant impact on patient experience.

End of life care plays an important role in the experiences of dying patients. Unfortunately, a comparative survey by Low et al (2017) of 514 health care professionals, to determine knowledge and practice patterns of palliative care in liver cirrhosis, found professionals felt ill prepared to 
provide good care to dying patients. Suggesting further training was needed to manage liver-related symptoms and issues.

\section{ii) Educational needs of Gastroenterology Nurses}

Examples of how the educational needs of Gastroenterology nurses can be identified and how support for nurses to improve their knowledge and competence vary widely in methods. Research strategies range from individual case studies, to using multicentre surveys, far-reaching webquestionnaires, and validated tools to help to identify gaps in knowledge and target learning. The evidence base that underpins practice is considered, as well as support required for role transition.

Identifying knowledge gaps is important for addressing learning needs. Hopchirk (2017) take an interesting approach using an online survey to complete a needs analysis of the education required by nurse endoscopists practicing in America. Although the sample size was small (only 7 endoscopists) the survey revealed interest to explore and possibly launch an interactive gastroenterology educational system, such as a community of practice to improve knowledge, technical skills and increase access to CRC screening/surveillance to improve patient outcomes.

There are a handful of quasi -experimental studies that use pre and post testing of knowledge following educational interventions to understand specific learning needs. Studies include those performed by Elkin et al (2018), where participation in a multi-media module on Coeliac disease, improved nurse practitioner knowledge levels and confidence significantly, and led to improved recognition and diagnosis for patients. Kao et al (2012) also compared the effects of two different educational interventions; a pocket booklet and a multimedia CDROM, to assist nurses conveying gastroscopy related information to patients. Finding that knowledge and competence improved and 
was significantly higher in the multimedia group. And although limited to a single UK centre, a study by Conley et al (2017) showed a simple teaching session on PEG care successfully identified gaps in knowledge, and improved confidence in nurses and safety for patients. This was useful for training in a specific competency and similar small studies looked at the impact of measurable implementations and/ or specific training and competencies. For example, in a study by Covington et al (2019) an online educational intervention with practical simulation was found to increase and sustain nurses' knowledge and self-efficacy in assessment, recognition, and treatment of airway emergencies in a gastroenterology clinic. Widening the scope beyond a specific task or skill; in a continuous formalised programme of education, Embertson et al (2020) enabled endoscopy staff to standardise care and maintain competency with new equipment and technology in procedures, improving staff satisfaction as a result.

To explore studies specific to EBP; in a replication of research by Pravikoff et al (2005), a questionnaire-based study by Baker, Ellett \& Sharon, (2010) performed to ascertain EBP in 225 American Gastroenterology nurses, less than a third of nurses used evidence to support their practice. Results showed that nurses lacked the understanding and skills required to search for literature using databases and would, for instance, prefer to ask colleagues for advice or type into an internet search engine. Most nurses read two-three journal articles annually, grading themselves as 'novice' at critically appraising research. Searching skills to find current evidence was described as essential by Barnwell (2016) in their case study of specialist nurses' approach to practice. Stating competent practitioners must be knowledgeable on the latest advances in the clinical area for decision making. Yet more consideration needs to be given to once evidence is found, how nurses develop the critical analysis skills required to fully understand and use evidence effectively in practice. Critical analysis skills have historically been taught as part of degree pathways. Potentially 
setting nurses who have trained before the advent of degree-based nurse training or not had the opportunity of further post graduate study, and their patients at a disadvantage (Taylor et al 2016).

Studies performed by Barnwell (2016), Brotherton et al (2013), Gee et al (2019), Sephton \& Kemp (2013) and Norton (2012) explore the transition to advanced nursing roles and highlight the importance of further training and academic education, drawing on evidence and assurance of competency. Norton (2012) suggest specialist GI nursing roles require education comparable to medical knowledge and skill with nurses training at masters and doctoral levels. The Royal College of Nursing (RCN) endorses this, stating Advanced Nurse Practitioners should be educated to Master's level, using expert knowledge and skills with critical analysis of evidence and assessed as clinically competent (RCN, 2018). This goes a long way to ensure EBP but assurance of competency in these roles also needs to be considered in the absence of UK regulation on advanced practice roles (Sephton \& Kemp 2013).

\section{iii) Solution based approaches to education and EBP.}

There are many remedies to improve the knowledge and skills of Gastroenterology Nurses, however, the best educational approach is yet to be defined (Naghdi et al., 2017). Consideration should be given to how individuals, institutions and organisations can support the development of knowledge, critical analysis skills and competency to deliver evidenced based care (Baker et al., 2010; Haycock et al., 2012; Norton, 2012 and Taylor et al., 2016).

\section{Individual/local level}

Examples of individuals' efforts to educate and develop themselves include reading peer reviewed journal articles and using online educational resources (Baker, Ellett \& Sharon, 2010). In their standards of practice and competencies for gastroenterology nurses Bocian et al, (2020) highlight 
the benefits of experiential bedside teaching and learning from local experienced nurses through informal mentorship, peer guidance and practical support.

Formal preceptorship has been found to improve the experience of new nurses and even decrease staff turnover (Gee et al., 2019; Norton, 2012). Nursing leaders should perhaps consider creating bespoke preceptorship packages in specialist areas when looking at retention for their workforces. To do this healthcare teams can adopt 'in house' approaches, using local resources, providing informal teaching, and developing their own study sessions. A successful example is provided by the quasi-experimental study by Gardner (2016) that found a single-unit pilot education programme could be provided economically, by existing staff, within working hours and improved staff satisfaction.

Simulation training has also been cited as an effective local educational strategy. Haycock et al, (2012) and more recently Dokoutsidhou et al (2020) used simulation to provide 'mock' rehearsal in the workplace, providing opportunities to practice scenarios and skills without affecting real patients. Improving team competencies as a result.

Local Trust librarians are also a valuable resource, providing a learning environment and teaching literature and database search skills; helping nurses to seek out reliable evidence to underpin their practice (Baker et al., 2010).

\section{Regional/ University accredited education}

As set out by the NHS Long term plan (NHS England 2019), UK government and healthcare organisations should provide funding for their nurses to attend regional events, such as workshops, study days and conferences. Although, attention must be given to accredited university courses, which provide the academic support required to develop the critical analysis skills vital for nurses to deliver EBP. This is important as we know nurses lack confidence and competence in this area (Elkin 
et al.,2018 and Kao et al., 2013). Baker et al., (2010) \& Taylor et al., (2016) agree that unless nurses possess the skills required to locate, appraise, and organise evidence, interpreting it into the practicalities for decision making, they will struggle to truly practice in an evidenced based way and directly influence better patient care. At the same time, we must acknowledge how access to university-based education can be difficult, when even the most motivated individuals struggle for varying reasons, including competing clinical demand, a lack of study time and resources, and funding restrictions placed upon organisations and employers (Taylor et al., 2016).

Perhaps blended learning is happy medium, combining academic training with practical experience gained in clinical areas, like the American Nurse Fellowship Programme for EPB by SGNA \& The Joanna Briggs Institute (Daniels \& Schmelzer 2012), the Australian Graduate Certificate in nurse endoscopy (Fox, Theobald \& Yates 2016) and the UK St Mark's Burdett Nurse Scholarship Programme (Taylor et al 2016). These scholarships supported by supernumerary placements are good examples of practice- based learning, yielding improved motivation, clinical and critical skills, delivery of EBP and dissemination of knowledge gained through publications and presentations at professional conferences.

\section{National level}

There are a wide range of clinical guidelines from organisations including the National Institute for Health and Care Excellence (NICE) and the British Society of Gastroenterology (BSG). Disease specific guidelines can help to improve the knowledge of individuals and healthcare organisations to achieve high standards of care for patients. Yet, it should be considered that this evidence can be limited. Indeed, it is only useful if it is interpreted and used as intended and may not be updated in timely response to new evidence provided by clinical trials. 
Ensuring standards of knowledge and competence in Gastrointestinal Nursing can also be supported in practice by accreditation standards and frameworks (Sephton \& Kemp, 2013). The IBD UK standards, statement 6.1 says patients requiring care for IBD should be admitted to specialist ward areas, under the care of a consultant gastroenterologist and/or colorectal surgeon (IBD UK 2019). This however assumes that specialist areas will provide a better standard of care to patients with IBD. We know from Sephton et al's (2013) questionnaire-based study in England that this is not always the case, again suggesting there is a need to target specialist education.

Good examples of frameworks that consider the underpinning development required include The Joint Advisory Group on Gastrointestinal Endoscopy (JAG) Accreditation Standards for Endoscopy Services (JAG, 2016) which promote measurable internal service appraisal, ensuring the competency and professional development of staff is prioritised. This notion is complimented by the 'JETS Workforce', e-portfolio which drives endoscopy specific competencies (JAG, 2019) and standards of practice and competencies, like those for American, Canadian and Chinese gastroenterology nurses (Bocian., et al 2020 and Ren et al 2019). The Royal College of Nursing; Caring for People with Liver Disease including Liver Transplantation: A Competence Framework for Nursing (RCN 2019) supports professional learning and development of individuals, being specific about the level of knowledge and skills required to demonstrate competency in different roles, in a reflective way, highlighting learning needs to the user (Clayton \& Greenslade 2014). Sephton \& Kemp (2013) echo the idea that more competency frameworks in specific specialist nursing roles would complement any future NMC regulation of ANP roles.

\section{Conclusion}

Whilst many of the studies included in this scoping review contain small sample sizes and are limited to single centres, they are consistent in their findings. Gastroenterology nurses' knowledge requires attention. Indicating more support in education is required, to improve both confidence and evidence based clinical practice of nurses, and the experiences and morbidity of patients. As 
gastroenterology nurses work across a broad range of pathologies and a diversity of clinical settings, it is difficult to establish a 'one size fits all' approach to education due to the differing levels of need. Solutions do not need to be expensive or time consuming and can be practical, utilising existing resources and delivered at individual, local, regional, and national levels (Baker et al., 2010). EBP is crucial to foster improvements in nursing care and patient outcomes. Indeed, whilst many nurses are aware of the importance EBP, they lack the resources, skills, and confidence necessary to implement it practically (Baker et al., 2010). Though academic education in specialist areas has been shown to combat this, equipping nurses with the critical analysis skills required, it is important to acknowledge accessing education can be difficult, with individuals struggling for varying organisational reasons (Taylor et al., 2016). Nurse educators must therefore be more creative in their approaches to nurture gastroenterology nurses' education, using a range of resources including reflection, journal clubs, mentorship, bedside teaching, and webinars. Drawing on national clinical guidelines and accreditation standards/ frameworks (Naghdi et al 2017) and by Universities working more cohesively with health care Trusts to deliver accredited blended learning programmes (Fox et al 2016; Gee, et al 2019 and Taylor et al., 2016).

Future researchers should consider further exploration of the instruments used to measure EBP and competence of Gastroenterology nurses, to evaluate the effectiveness of different educational models and assist educators in the development and refinement of content and delivery. 


\section{$\underline{\text { References }}$}

Aladul, M., Fitzpatrick, R. \& Chapman, S. (2018). Differences in UK healthcare professionals' knowledge, attitude and practice towards infliximab and insulin glargine biosimilars. International Journal of Pharmacy Practice, 27(2) 214-217.

Arksey, H. \& O'Malley, L. (2005). Scoping studies: towards a methodological framework. International Journal of Social Research Methodology, 8(1) 1-9.

Baker, K.A., Ellett, M.L. \& Sharon, D.B. (2010). Evidence-Based Practices of Gastroenterology Nurses. Gastroenterology Nursing, 33(4) 263-266.

Barnwell, A. (2016). Examining the decision-making theories employed by nurses to diagnose a patient presenting with a rectal bleed. Gastrointestinal Nursing, 14 (1) 18-25.

Bocian, S., Loyola, M., Benitez-Romero, M., Friis, C., Granato, A., Penberthy, J., ... Wahinehookae, C. (2020). S tandards of clinical nursing practice and role delineations in the gastroenterology setting. Gastroenterology Nursing. 43 (3) E129-E141.

Brotherton, C. S., Taylor, A.G. \& Keeling, A. (2013). Fire in the Belly and the Professionalization of Nurses: A Historical Analysis of Crohn Disease Care. Gastroenterology Nursing, 36 (1) 21-28.

Clayton, M., \& Greenslade, L. (2014). A framework to develop nurses' liver care skills. Nursing Times. 110 (30) 20-23.

Conley, T., Povah, M., Collins, B., Theis, V. \& Fox, M. (2017). Percutaneous endoscopic gastrostomy care? A prospective evaluation of a simple teaching intervention in improving nursing knowledge and confidence. Gut, 66: A51-A52.

Covington, C., Muckler, V., Sheldon, L., Alexander, R., \& Morgan, B. (2019). Improving Emergency Airway Knowledge and Self-Efficacy Levels of Outpatient Gastroenterology Staff via Implementation of Online Education and In Situ Simulation. Gastroenterology Nursing. 42 (3) 242-250.

Daniels, G., \& Schmelzer, M. (2012) The Society of Gastroenterology Nurses and Associates has a new nurse fellowship program for evidence-based practice. Gastroenterology Nursing. 35 (2) 130141.

Davis, K., Drey, N., \& Gould, D. (2009). What are scoping studies? A review of the nursing literature. International Journal of Nursing Studies, 46 (10)1386-1400.

Dokoutsidou, E., Alodat, M., Mavrogiannis, C., Georgiou, K., Giannakoulopoulou, E.,Galanis, P., ... Georgiou, E. (2020). Performance Assessment of Subjects With Nursing Education Trained in Sigmoidoscopy by Means of a Simulator. Gastroenterology Nursing. 43 (6) 411-421.

Elkin, A.M., Grant, C., Coleman, T. \& Sereika, S. M. (2018). Use of an Educational Module to Improve Confidence and Knowledge of Celiac Disease Among Nurse Practitioners in Pennsylvania: A QuasiExperimental Mixed-Methods Design. Gastroenterology Nursing, 41(5), 412-423. 
Embertson, A., Ernst, N., Yoder, J., Monroe, L., \& Hess, M. (2020). Development of a Nurse-Led Competency-Based Program for Therapeutic Endoscopy. Gastroenterology Nursing. 43 (6) E217E224.

Embleton R., \& Henderson M. (2020). Overcoming barriers to nurses performing digital rectal examination. Nursing Times. 116 (9) 42-44.

Feng, P., Yang, H., Xu, L., Ojo, O., Lu, X., Zhang, H., \& Wang, X. (2021). Development and psychometric testing of a questionnaire to assess Nurse's perception of risks during enteral nutrition. Biomed Central (BMC) Nursing. 20 (6) 1-9.

Fox, A., Theobald, K., \& Yates, P. (2016). Nurses report formal education improves practice. Australian Nursing \& Midwifery Journal. 24 (4) 35.

Gardner, S. (2016). Improving Staff Satisfaction Through Peer-Led Professional Development. Gastroenterology Nursing. 39 (2) 96-100.

Gee, C., Andreyev, J., \& Muls, A. (2019). Developing advanced clinical practice skills in gastrointestinal consequences of cancer treatment. British Journal of Nursing, 27 (5) 237-247.

Grant, M. J. \& Booth, A. (2009). A typology of reviews: An analysis of 14 review types and associated methodologies. Health Information \& Libraries Journal, 26 (2) 91 -108.

Groenkjaer, L. (2015). Oral Care in Hepatology Nursing: Nurses' Knowledge and Education. Gastroenterology Nursing, 38(1) 22-30.

Haycock, A., Matharoo, M.K. \& Thomas-Gibson, S. (2012). Effective teamworking in gastroenterology. Frontline Gastroenterology, 3(2) 86-89.

Hopchik, J. (2017). Needs Assessment Survey for Nurse Practitioner and Physician Assistant Colonoscopists for a Gastroenterology Community of Practice. Gastrointestinal Nursing. 40 (3) 222228.

IBD UK (2019). IBD Standards. Crohn's \& Colitis UK.

Joint Advisory Group on Gastrointestinal Endoscopy (JAG) (2016). Accreditation standards for endoscopy services. London: Royal College of Physicians.

Joint Advisory Group on Gastrointestinal Endoscopy (JAG) (2019) JETS workforce. London: Royal College of Physicians. Retrieved 24/04 19 from

https://www.thejag.org.uk/CMS/Page.aspx?Pageld=113

Joukar, F., Mansour-Ghanaei, F., Soati, F. \& Meskinkhoda, P. (2012). Knowledge levels and attitudes of health care professionals toward patients with hepatitis $\mathrm{C}$ infection. World Journal of Gastroenterology, 18(18) 2238-2244.

Kao, S., Hsu, L., Hsieh, S. \& Huang, T. (2013). The effects of two educational interventions on knowledge and competence of nurses with regard to conveying gastroscopy-related information to patients. Journal of Advanced Nursing, 69 (4) 793-804.

Kelly, P. P. (2015). Colorectal Cancer Family History Assessment. Clinical Journal of Oncology Nursing, 15 (5) E75-E82. 
Lang, B., Velez, R., Reiley, J., \& Steinberg, M. (2020). A Collaborative Survey of Nurse Practitioner Colorectal Cancer Screening Practice. The Journal for Nurse Practitioners. 16 (2020) e143- e147.

Levac, D., Colquhoun, H. \& O’Brien, K.K. (2010). Scoping studies: advancing the methodology. Implementation Science, 5 (69) 1-9.

Low, J., Vickerstaff, V., Davis, S., Bichard, J., Greenslade, L., Hopkins, K., ...Jones, L. (2016). Palliative care for cirrhosis: a UK survey of health professionals' perceptions, current practice and future needs. Frontline Gastroenterology, 7(1) 4-9.

Meriam Library (2019). Is this source or information good? CRAAP test. California State University Chico. Accessed 16/08/19 from https://library.csuchico.edu/help/source-or-information-good

Naghdi, R, Seto, K, Klassen, C, Emokpare, D, Conway, B, Kelley,....... Shah, H, A (2017). A Hepatitis C Educational Needs Assessment of Canadian Healthcare Providers. Canadian Journal of Gastroenterology and Hepatology. 2017: 1- 10. doi.org/10.1155/2017/5324290

NHS England (2017). Finding the evidence: A key step in the information production process. NHS England.

NHS England (2019). NHS Long term plan. NHS England

Norton, C. (2012). The future of gastroenterology nursing. Frontline Gastroenterology. 3 1): i6-i8.

Nursing \& Midwifery Council (2019). Revalidation. London: NMC.

Nursing \& Midwifery Council (2018a). The Code: Professional standards of practice and behaviour for nurses, midwives and nursing associates. London: NMC.

Nursing \& Midwifery Council (2018b). Future nurse: Standards of proficiency for registered nurses. London: NMC

Pham, M. T., Rajic, A., Greig, J. D., Sargeant, J. M., Papadopoulos, A. \& McEwan, S. A. (2014). A scoping review of scoping reviews: Advancing the approach and enhancing consistency. Research Synthesis Methods, 5 (4) 371-385.

Pravikoff, D. S., Tanner, A. B., \& Pierce, S. T. (2005). Readiness of U.S. Nurses for Evidence-Based Practice. American Journal of Nursing, 105 (9)40-51.

Ren, H., Changqing, L,. Wang, R., Zhang, M., Ma, F., Li, R., ... Luohong, L. (2019). Core Competencies Required for Gastroenterology Nursing Specialists in China. Gastroenterolgy Nursing. 42 (2) 169-178.

Royal College of Nursing (2019). Caring for People with Liver Disease including Liver Transplantation: a Competence Framework for Nursing. London: RCN.

Royal College of Nursing (2018). RCN Standards for Advanced Level Nursing Practice. London: RCN.

Sephton, M. \& Kemp, K. (2013). A competency framework for inflammatory bowel disease nurses. Nursing Standard, 27 (38) 41-45.

Sephton, M.L., Tattersall, S., Kemp, K., Hurst, A., Gray, L. B., Gregg, A. M., Hall, V. (2013). A Comparison of Gastroenterology and Non-Gastroenterology Nurses Knowledge of Inflammatory Bowel Disease. Gastroenterology, 144 (5), S570. 
Taylor, C., Burch, J. \& Black, P. (2016). Developing the specialist gastrointestinal nurses of the future: the St Mark's Burdett Nurse Scholarship Programme. Gastrointestinal Nursing, 14 (5) 12-21. 


Table 1 Database search results
\begin{tabular}{|l|l|l|}
\hline Search term & 600 & 15 \\
\hline Nurse knowledge AND Gastroenterology & \multicolumn{1}{l|}{$\begin{array}{l}\text { British } \\
\text { Nursing Index }\end{array}$} \\
\hline $\begin{array}{l}\text { MEDLINE } \\
\text { Gastroenterology Nurses AND evidence-based practice AND } \\
\text { knowledge }\end{array}$ & 388 & 12 \\
\hline Gastroenterology Nurses AND knowledge AND education & 415 & 424 \\
\hline
\end{tabular}

\begin{tabular}{|c|c|c|c|c|}
\hline Table 2 & & & & \\
\hline $\begin{array}{l}\text { Author (year } \\
\text { of } \\
\text { publication) }\end{array}$ & Study populations & Aims of the study & Methodology & Results \\
\hline $\begin{array}{l}\text { Aladul, } \\
\text { Fitzpatrick \& } \\
\text { Chapman } \\
\text { (2018). }\end{array}$ & $\begin{array}{l}234 \text { UK Specialist } \\
\text { Consultants, Nurses and } \\
\text { Pharmacists. }\end{array}$ & $\begin{array}{l}\text { Investigate factors } \\
\text { influencing biosimilar } \\
\text { prescribing practice. }\end{array}$ & $\begin{array}{l}\text { Correlational design } \\
\text { using an online } \\
\text { survey. }\end{array}$ & $\begin{array}{l}\text { Consultants and Pharmacists were well informed, with comparable levels of awareness of } \\
\text { biosimilars used. Nurses were less well informed. All differed in opinions regarding factors } \\
\text { influencing prescribing. }\end{array}$ \\
\hline $\begin{array}{l}\text { Baker, Ellett \& } \\
\text { Sharon (2010). }\end{array}$ & $\begin{array}{l}225 \text { Members of the Society } \\
\text { of Gastroenterology Nurses } \\
\text { and Associates (SGNA) }\end{array}$ & $\begin{array}{l}\text { Investigate the EBP of } \\
\text { Gastroenterology Nurses in } \\
\text { the USA. }\end{array}$ & $\begin{array}{l}\text { Descriptive, design } \\
\text { using an online } \\
\text { survey. }\end{array}$ & $\begin{array}{l}\text { Gastroenterology nurses are aware of EBP yet lack the skills and resources necessary to } \\
\text { implement it. Efforts at the national, regional, local, and individual levels are necessary to } \\
\text { promote the use of EBP in gastroenterology nursing practice. }\end{array}$ \\
\hline $\begin{array}{l}\text { Barnwell } \\
\text { (2016). }\end{array}$ & $\begin{array}{l}\text { A colorectal and stoma nurse } \\
\text { specialist. }\end{array}$ & $\begin{array}{l}\text { A critical evaluation of } \\
\text { decision-making theories } \\
\text { that inform practice. }\end{array}$ & A reflective case study & $\begin{array}{l}\text { Structured models provide a comprehensive approach to decision making; however, EBP is } \\
\text { dependent on the theoretical and clinical knowledge of the nurse specialist, therefore the } \\
\text { competent practitioner must be knowledgeable on the latest advances in the clinical area. }\end{array}$ \\
\hline $\begin{array}{l}\text { Bocian., et al } \\
(2020)\end{array}$ & & $\begin{array}{l}\text { Provide standards of practice } \\
\text { and competencies for } \\
\text { American and Canadian } \\
\text { gastroenterology nurses. }\end{array}$ & $\begin{array}{l}\text { Clinical practice } \\
\text { guideline }\end{array}$ & $\begin{array}{l}\text { Nurses should attain knowledge and competence that reflects current gastroenterology } \\
\text { nursing practice, with a life-long commitment to reflective learning, sharing educational } \\
\text { findings, role modelling and mentoring peers. Integrating the findings of peer-reviewed, } \\
\text { published scientific evidence and research into practice. }\end{array}$ \\
\hline $\begin{array}{l}\text { Brotherton } \\
\text { Taylor \& } \\
\text { Keeling (2013). }\end{array}$ & $\begin{array}{l}\text { Nurses specialising in IBD } \\
\text { care. }\end{array}$ & $\begin{array}{l}\text { Describe and analyse the } \\
\text { development of the role of } \\
\text { IBD specialist nurses. }\end{array}$ & Literature review & $\begin{array}{l}\text { Nurses with specialised knowledge and skills help stretch limited resources to meet rising } \\
\text { healthcare demands. Nurses practicing in advanced practice roles are increasingly filling } \\
\text { the gaps in IBD. }\end{array}$ \\
\hline
\end{tabular}




\begin{tabular}{|c|c|c|c|c|}
\hline $\begin{array}{l}\text { Clayton \& } \\
\text { Greenslade } \\
(2014)\end{array}$ & & $\begin{array}{l}\text { Describe how a national } \\
\text { competency framework was } \\
\text { developed and can be used } \\
\text { by nurses caring for people } \\
\text { with liver disease. }\end{array}$ & $\begin{array}{l}\text { Double blind peer } \\
\text { reviewed literature } \\
\text { review. }\end{array}$ & $\begin{array}{l}\text { The framework can be used to help nurses to identify their own or their teams learning } \\
\text { needs, and develop the skills and knowledge required to build a personal portfolio of } \\
\text { competencies. }\end{array}$ \\
\hline $\begin{array}{l}\text { Conley, Povah, } \\
\text { Collins, Theis \& } \\
\text { Fox (2017). }\end{array}$ & $\begin{array}{l}83 \text { nurses (gastroenterology, } \\
\text { elderly, and acute medicine) } \\
\text { at Whiston Hospital, England. }\end{array}$ & $\begin{array}{l}\text { Determine nursing } \\
\text { knowledge and confidence } \\
\text { of percutaneous endoscopic } \\
\text { gastrostomy (PEG) care. } \\
\text { Evaluate the efficacy of a } \\
\text { simple teaching programme. }\end{array}$ & $\begin{array}{l}\text { A single centre quasi- } \\
\text { experimental design, } \\
\text { using a safety } \\
\text { screening } \\
\text { questionnaire. Re- } \\
\text { audited following } \\
\text { delivery of a teaching } \\
\text { intervention. }\end{array}$ & $\begin{array}{l}\text { Baseline knowledge and confidence was lacking. An education session successfully } \\
\text { improved confidence and deterred potentially dangerous behaviours. }\end{array}$ \\
\hline $\begin{array}{l}\text { Covington, } \\
\text { Muckler, } \\
\text { Sheldon, } \\
\text { Alexander \& } \\
\text { Morgan (2019) }\end{array}$ & $\begin{array}{l}14 \text { registered nurses and } 7 \\
\text { technicians in a } \\
\text { gastroenterology outpatient } \\
\text { clinic in North Carolina USA. }\end{array}$ & $\begin{array}{l}\text { To increase and sustain } \\
\text { nurses' knowledge and self- } \\
\text { efficacy in assessment, } \\
\text { recognition, and treatment } \\
\text { of airway emergencies. }\end{array}$ & $\begin{array}{l}\text { A single centre, quasi } \\
\text { experimental design } \\
\text { with a pre- and post- } \\
\text { knowledge test. Using } \\
\text { online education and } \\
\text { practical simulation. }\end{array}$ & $\begin{array}{l}\text { Analysis showed statistically significant increases in both knowledge scores and levels of } \\
\text { self-efficacy in immediate and post education assessments. }\end{array}$ \\
\hline $\begin{array}{l}\text { Daniels \& } \\
\text { Schmelzer } \\
(2012)\end{array}$ & $\begin{array}{l}\text { Dr Susan Weeks Director of } \\
\text { the TCU Centre for EBP and } \\
\text { Research. }\end{array}$ & $\begin{array}{l}\text { To give SGNA members a } \\
\text { better understanding of a 2- } \\
\text { year Nurse Fellowship } \\
\text { Programme for EPB by SGNA } \\
\text { \& The Joanna Briggs Institute } \\
\text { (JBI). }\end{array}$ & $\begin{array}{l}\text { A case study narrative } \\
\text { transcript of a } \\
\text { structured peer } \\
\text { interview. }\end{array}$ & $\begin{array}{l}\text { Fellows benefit from professional networking and mentorship to develop an evidence- } \\
\text { based project addressing a specific gastroenterology nursing problem and disseminate } \\
\text { findings through publications and presentations at professional conferences. }\end{array}$ \\
\hline $\begin{array}{l}\text { Dokoutsidhou. } \\
\text { et al (2020) }\end{array}$ & $\begin{array}{l}12 \text { nurses with and } 14 \text { nurses } \\
\text { without endoscopy unit } \\
\text { experience as well as } 18 \\
\text { nursing students at a Medical } \\
\text { Physics Simulation Centre. } \\
\text { University of Athens. }\end{array}$ & $\begin{array}{l}\text { Assess performance of } \\
\text { nurses in simulated } \\
\text { sigmoidoscopy training and } \\
\text { the impact on performance } \\
\text { of endoscopy unit } \\
\text { experience, professional } \\
\text { experience, and practical } \\
\text { skills. }\end{array}$ & $\begin{array}{l}\text { Single centre quasi } \\
\text { experimental } \\
\text { prospective } \\
\text { nonrandomised study } \\
\text { design. Using } \\
\text { endoscope simulation } \\
\text { software with } \\
\text { performance metrics. }\end{array}$ & $\begin{array}{l}\text { Training nurses in simulated sigmoidoscopy is feasible using a proper training program. } \\
\text { Experience in endoscopy unit and skills in manual activities have a positive impact on the } \\
\text { training process. }\end{array}$ \\
\hline
\end{tabular}




\begin{tabular}{|c|c|c|c|c|}
\hline $\begin{array}{l}\text { Elkin, Grant, } \\
\text { Coleman \& } \\
\text { Sereika (2018). }\end{array}$ & $\begin{array}{l}13 \text { American Nurse } \\
\text { Practitioners. }\end{array}$ & $\begin{array}{l}\text { To investigate the effect of a } \\
\text { multi-media education } \\
\text { intervention on Nurse } \\
\text { Practitioner confidence and } \\
\text { knowledge of coeliac } \\
\text { disease. }\end{array}$ & $\begin{array}{l}\text { A single group mixed } \\
\text { methods design with } \\
\text { prospective data } \\
\text { collection using an } \\
\text { online pre and post } \\
\text { learning test, with } \\
\text { follow-up surveys }\end{array}$ & $\begin{array}{l}\text { Nurse practitioner confidence and knowledge levels improved after participation in the } \\
\text { educational intervention and their clinical practice changed to include recognition and } \\
\text { diagnosis. }\end{array}$ \\
\hline $\begin{array}{l}\text { Embertson, } \\
\text { Ernst, Yoder, } \\
\text { Monroe \& Hess } \\
\text { (2020) }\end{array}$ & $\begin{array}{l}39 \text { nurses and } 10 \text { supportive } \\
\text { personnel at John Hopkins } \\
\text { Hospital USA. }\end{array}$ & $\begin{array}{l}\text { Illustrate how an education } \\
\text { programme enable's } \\
\text { endoscopy staff to } \\
\text { standardise care and } \\
\text { maintain competency with } \\
\text { new equipment and } \\
\text { technology and assess } \\
\text { satisfaction with support and } \\
\text { education provided. }\end{array}$ & $\begin{array}{l}\text { Single centre quasi- } \\
\text { experimental design } \\
\text { using pre and post } \\
\text { education programme } \\
\text { surveys to self- } \\
\text { evaluate competency, } \\
\text { and satisfaction. }\end{array}$ & $\begin{array}{l}\text { Staff did not feel competent or supported and expressed dissatisfaction with the current } \\
\text { education provided. The educational programme was introduced using multiple learning } \\
\text { resources. Staff's satisfaction of education and resources was improved. Overall } \\
\text { communication and collaboration in endoscopy improved and as a result, professional } \\
\text { relationships and teamwork was strengthened. }\end{array}$ \\
\hline $\begin{array}{l}\text { Embleton \& } \\
\text { Henderson } \\
(2020)\end{array}$ & $\begin{array}{l}182 \text { registered UK nurses who } \\
\text { administer rectal medication. }\end{array}$ & $\begin{array}{l}\text { To understand why nurses } \\
\text { do not always perform } \\
\text { digital rectal examination } \\
\text { (DRE) before, and after } \\
\text { administering rectal } \\
\text { medication. }\end{array}$ & $\begin{array}{l}\text { A descriptive study } \\
\text { using a questionnaire } \\
\text { via Twitter targeting } \\
\text { nurses through } \\
\text { hashtags/ retweets to } \\
\text { nurse's networks. }\end{array}$ & $\begin{array}{l}\text { The survey demonstrated a lack of awareness of the need for DRE. A lack of competence in } \\
\text { and a fear of performing DRE. } 38 \% \text { of respondents said they had not received any formal } \\
\text { DRE training. }\end{array}$ \\
\hline $\begin{array}{l}\text { Feng. et al } \\
(2021)\end{array}$ & $\begin{array}{l}352 \text { nurses from five tertiary } \\
\text { hospitals in China }\end{array}$ & $\begin{array}{l}\text { Evaluate risk perception of } \\
\text { enteral nutrition (EN). }\end{array}$ & $\begin{array}{l}\text { A multi-centre mixed } \\
\text { method study using } \\
\text { convenience sampling } \\
\text { with a questionnaire. }\end{array}$ & $\begin{array}{l}\text { Nurses' different educational backgrounds had a significant difference of EN risk } \\
\text { perception. The questionnaire can be used as a tool to assess nurses' EN risk perception } \\
\text { ability, to help to reduce adverse events during EN implementation by targeting education. }\end{array}$ \\
\hline $\begin{array}{l}\text { Fox, Theobald } \\
\text { \& Yates (2016) }\end{array}$ & $\begin{array}{l}45 \text { nurse endoscopy students } \\
\text { from Queensland Australia }\end{array}$ & $\begin{array}{l}\text { Evaluation of a Graduate } \\
\text { certificate course in nurse } \\
\text { endoscopy. }\end{array}$ & $\begin{array}{l}\text { A descriptive design } \\
\text { using a survey } \\
\text { distributed } \\
\text { electronically. }\end{array}$ & $\begin{array}{l}\text { Knowledge gained by students on the course was applied in the workplace. Formal } \\
\text { education as an asset to improving practice. }\end{array}$ \\
\hline Gardner (2016) & $\begin{array}{l}20 \text { Registered Nurses in a } \\
\text { gastroenterology } \\
\text { hospital/clinic in lowa USA }\end{array}$ & $\begin{array}{l}\text { Explore whether education } \\
\text { could be provided } \\
\text { economically, by existing } \\
\text { staff, within working hours }\end{array}$ & $\begin{array}{l}\text { Single centre quasi- } \\
\text { experimental design. } \\
\text { Efficacy was } \\
\text { measured by }\end{array}$ & $\begin{array}{l}\text { The pilot study demonstrates that peer education can be provided on a unit level, meeting } \\
\text { national certification goals for best practices and patient outcomes. }\end{array}$ \\
\hline
\end{tabular}




\begin{tabular}{|c|c|c|c|c|}
\hline & & $\begin{array}{l}\text { to meet the requirements of } \\
\text { re-certification and improve } \\
\text { staff satisfaction. }\end{array}$ & $\begin{array}{l}\text { engagement with the } \\
\text { education pilot. } \\
\text { Satisfaction was } \\
\text { evaluated with pre- } \\
\text { pilot/post-pilot } \\
\text { surveys. }\end{array}$ & \\
\hline $\begin{array}{l}\text { Gee, } \\
\text { Andreyev, \& } \\
\text { Mulls (2019). }\end{array}$ & $\begin{array}{l}\text { The first } 50 \text { patients assessed } \\
\text { by the nurse specialist. }\end{array}$ & $\begin{array}{l}\text { Explore the transition from } \\
\text { nurse specialist to advanced } \\
\text { clinical practitioner within a } \\
\text { GI cancer clinic. }\end{array}$ & $\begin{array}{l}\text { Descriptive, } \\
\text { prospective service } \\
\text { evaluation, and a } \\
\text { reflective journaling. }\end{array}$ & $\begin{array}{l}\text { Reflective journaling allows for identification individual of learning needs. Education in the } \\
\text { form of blended learning; formal training, shadowing, using clinical assessment } \\
\text { tools/guidelines and personal reflection of practice was essential to transition. }\end{array}$ \\
\hline $\begin{array}{l}\text { Groenkjaer } \\
\text { (2015). }\end{array}$ & $\begin{array}{l}94 \text { gastroenterology nurses in } \\
\text { Denmark. }\end{array}$ & $\begin{array}{l}\text { Explore nurses' knowledge } \\
\text { and education in the oral } \\
\text { care of patients with liver } \\
\text { cirrhosis. }\end{array}$ & $\begin{array}{l}\text { A multi-centre } \\
\text { descriptive design } \\
\text { using a questionnaire. }\end{array}$ & $\begin{array}{l}\text { Respondents had inadequate knowledge on oral care in liver disease, indicating a need for } \\
\text { educational updates and the promotion of specific oral assessment guides in liver cirrhosis. }\end{array}$ \\
\hline Hopchik (2017) & $\begin{array}{l}7 \text { credentialed non-physician } \\
\text { endoscopists (five Nurse } \\
\text { Practitioners and two } \\
\text { Physicians Assistants). }\end{array}$ & $\begin{array}{l}\text { A needs analysis of the } \\
\text { education required by } \\
\text { endoscopists practicing in } \\
\text { America. To understand how } \\
\text { knowledge and skills in } \\
\text { colorectal cancer screening } \\
\text { (CRC) might be improved. }\end{array}$ & $\begin{array}{l}\text { A descriptive design, } \\
\text { using an online survey } \\
\text { with Likert scale } \\
\text { measurement and } \\
\text { purposive, snowball } \\
\text { sampling technique. }\end{array}$ & $\begin{array}{l}\text { There is interest and motivation to explore and launch a nonphysician gastroenterology, } \\
\text { interactive communication, and educational system such as a community of practice to } \\
\text { improve knowledge and technical skills and increase access to CRC screening/surveillance. }\end{array}$ \\
\hline $\begin{array}{l}\text { Haycock, } \\
\text { Matharoo \& } \\
\text { Thomas-Gibson } \\
\text { (2012). }\end{array}$ & Gastroenterology teams. & $\begin{array}{l}\text { Explore the importance of } \\
\text { team-working in } \\
\text { gastroenterology teams and } \\
\text { its role in achieving quality } \\
\text { care and minimising medical } \\
\text { error. }\end{array}$ & Literature review & $\begin{array}{l}\text { Formal analysis of team objectives and identification of essential tasks allowed redesign of } \\
\text { team organisation and enabled structured training to strengthen team cohesion, enhance } \\
\text { critical team skills and improve clinical outcomes. }\end{array}$ \\
\hline $\begin{array}{l}\text { Joukar, } \\
\text { Mansour- } \\
\text { Ghanaei, Soati } \\
\text { \& Meskinkhoda } \\
\text { (2012). }\end{array}$ & $\begin{array}{l}239 \text { Iranian professionals } \\
\text { including Doctors, Nurses, } \\
\text { and Operating Room } \\
\text { Technicians. }\end{array}$ & $\begin{array}{l}\text { To study the knowledge and } \\
\text { attitudes of health care } \\
\text { providers toward patients } \\
\text { with hepatitis C virus } \\
\text { infection. }\end{array}$ & $\begin{array}{l}\text { A single centre } \\
\text { correlational cross- } \\
\text { sectional study using } \\
\text { validated } \\
\text { questionnaires. }\end{array}$ & $\begin{array}{l}\text { There was a positive correlation between knowledge and attitude scores meaning } \\
\text { education would improve the experiences and treatment of patients with Hep C. }\end{array}$ \\
\hline
\end{tabular}




\begin{tabular}{|c|c|c|c|c|}
\hline $\begin{array}{l}\text { Kao, Hsu, } \\
\text { Hsieh, \& Huang } \\
\text { (2012). }\end{array}$ & $\begin{array}{l}65 \text { Gastroenterology Nurses } \\
\text { in Taiwan divided into } 2 \\
\text { groups }\end{array}$ & $\begin{array}{l}\text { Compare the effects of two } \\
\text { educational interventions (a } \\
\text { CD-ROM and booklet) on } \\
\text { knowledge and competence } \\
\text { of nurses in conveying } \\
\text { gastroscopy related } \\
\text { information to patients. }\end{array}$ & $\begin{array}{l}\text { A quasi-experimental } \\
\text { multi-centre study. } \\
\text { Pre-test and two post- } \\
\text { tests using validated } \\
\text { scales. }\end{array}$ & $\begin{array}{l}\text { Both educational interventions improved nurses' knowledge, competence and quality of } \\
\text { information given to patients. The CD-ROM had long-term effects on knowledge and short- } \\
\text { term and long-term effects on competence. }\end{array}$ \\
\hline Kelly (2015). & $\begin{array}{l}88 \text { colonoscopy records were } \\
\text { surveyed, and } 16 \text { nurses were } \\
\text { interviewed in the USA. }\end{array}$ & $\begin{array}{l}\text { Examine family history } \\
\text { assessment for CRC in } \\
\text { outpatient gastroenterology } \\
\text { units and nurses' knowledge } \\
\text { and attitudes about family } \\
\text { history assessments. }\end{array}$ & $\begin{array}{l}\text { A mixed methods } \\
\text { multi-centre study. } \\
\text { Involving an audit of } \\
\text { medical records using } \\
\text { a researcher } \\
\text { developed tool and } \\
\text { convenience sampling } \\
\text { interview's }\end{array}$ & $\begin{array}{l}\text { Nurses rated family history as very important but limited history documentation was } \\
\text { present in } 95 \% \text { of patients with a family history of CRC. Indicating more education was } \\
\text { required. }\end{array}$ \\
\hline $\begin{array}{l}\text { Lang, Velez, } \\
\text { Reiley, \& } \\
\text { Steinberg } \\
\text { (2020) }\end{array}$ & $\begin{array}{l}88 \text { American Nurse } \\
\text { Practitioners (NP's) involved } \\
\text { in CRC screening including } \\
\text { Gastroenterology nurses. }\end{array}$ & $\begin{array}{l}\text { Assess NP knowledge, } \\
\text { beliefs, and practice patterns } \\
\text { for CRC screening }\end{array}$ & $\begin{array}{l}\text { A descriptive cross- } \\
\text { sectional electronic } \\
\text { survey. }\end{array}$ & $\begin{array}{l}\text { NPs' knowledge of CRC screening and methods were variable. NPs indicated patients were } \\
\text { often unaware of the importance of screening, highlighting an unmet need for NPs to } \\
\text { provide education to patients. Targeted education for nurse practitioners on CRC } \\
\text { screening guidelines and options is required to improve CRC rates. }\end{array}$ \\
\hline $\begin{array}{l}\text { Low et al, } \\
\text { (2016). }\end{array}$ & $\begin{array}{l}514 \text { respondents including } \\
\text { liver teams/nurses, palliative } \\
\text { care, and general practice } \\
\text { professionals }\end{array}$ & $\begin{array}{l}\text { To determine the knowledge } \\
\text { and practice of a UK cohort, } \\
\text { delivering palliative care in } \\
\text { cirrhosis, and to inform } \\
\text { priorities for future research. }\end{array}$ & $\begin{array}{l}\text { A correlational design } \\
\text { using on-line } \\
\text { questionnaire }\end{array}$ & $\begin{array}{l}\text { Referrals to palliative care teams are low. Many professionals felt ill prepared to provide } \\
\text { good care to those facing death. Further training is needed in managing liver-related } \\
\text { symptoms, symptom control and end of life issues. Prognostication, symptom } \\
\text { management and service configuration were key areas identified for future research. }\end{array}$ \\
\hline $\begin{array}{l}\text { Naghdi et al, } \\
\text { (2017). }\end{array}$ & $\begin{array}{l}163 \text { Canadian GI healthcare } \\
\text { practitioners including } \\
\text { nurses. }\end{array}$ & $\begin{array}{l}\text { Assess the current } \\
\text { knowledge and educational } \\
\text { needs of healthcare } \\
\text { providers in Hepatitis C } \\
\text { management }\end{array}$ & $\begin{array}{l}\text { A descriptive design } \\
\text { using a survey } \\
\text { designed by an inter- } \\
\text { professional steering } \\
\text { committee }\end{array}$ & $\begin{array}{l}\text { Nurses and primary physicians reported less confidence in screening and explaining Hep C } \\
\text { and treatment to patients and were less aware of medications available. Participants } \\
\text { reported inadequate access to funding and resources. National conferences, webinars, } \\
\text { lectures, guidelines and reading journal articles were cited as preferred methods of } \\
\text { learning. }\end{array}$ \\
\hline Norton (2012). & Gastroenterology nurses. & $\begin{array}{l}\text { To explore the history, } \\
\text { developing practice and the } \\
\text { future of gastroenterology } \\
\text { nursing. }\end{array}$ & Literature review & $\begin{array}{l}\text { Specialist GI nursing roles require training and education that is comparable to medical } \\
\text { knowledge and skill with nurses training at masters and doctoral levels. } \\
\text { Research exploring the clinical and cost effectiveness of specialist nurse training is } \\
\text { important to safeguard and continue development of roles. }\end{array}$ \\
\hline Ren et al (2019) & $\begin{array}{l}28 \text { Gastroenterology nurses } \\
\text { in China }\end{array}$ & $\begin{array}{l}\text { Proposal of core } \\
\text { competencies for }\end{array}$ & $\begin{array}{l}\text { A mixed methods } \\
\text { design with literature }\end{array}$ & $\begin{array}{l}\text { Competencies were proposed that enable gastro nurses to acquire knowledge and clinical } \\
\text { practices with advanced critical thinking skills that enhance patient safety. }\end{array}$ \\
\hline
\end{tabular}




\begin{tabular}{|c|c|c|c|c|}
\hline & & $\begin{array}{l}\text { gastroenterology nursing } \\
\text { specialists }\end{array}$ & $\begin{array}{l}\text { review and semi } \\
\text { structured interviews }\end{array}$ & \\
\hline $\begin{array}{l}\text { Sephton et al, } \\
\text { (2013). }\end{array}$ & $\begin{array}{l}80 \text { ward nurses sampled from } \\
\text { hospital Trusts in the North } \\
\text { West UK. }\end{array}$ & $\begin{array}{l}\text { Assess the knowledge base } \\
\text { of } 40 \text { nurses on a specialist } \\
\text { gastroenterology ward in } \\
\text { comparison to } 40 \text { non-gastro } \\
\text { nurses. }\end{array}$ & $\begin{array}{l}\text { A multi-centre } \\
\text { correlational design } \\
\text { using the validated } \\
\text { Crohn's and Colitis } \\
\text { knowledge (CCKNOW) } \\
\text { questionnaire. }\end{array}$ & $\begin{array}{l}\text { Non gastro nurses had more knowledge of the anatomy of the GI tract than Gastro nurses. } \\
\text { Gastro ward nurses were no more knowledgeable about GI diseases than non-gastro ward } \\
\text { nurses. More needs to be done to educate gastro ward nurses on the anatomy of the GI } \\
\text { tract and IBD. }\end{array}$ \\
\hline $\begin{array}{l}\text { Sephton \& } \\
\text { Kemp (2013). }\end{array}$ & $\begin{array}{l}\text { IBD Specialist and Advanced } \\
\text { Nurse Practitioners (ANP) }\end{array}$ & $\begin{array}{l}\text { Review evidence for } \\
\text { competency frameworks and } \\
\text { their contribution to IBD } \\
\text { specialist nurse practice in } \\
\text { the absence of UK regulation } \\
\text { on advanced practice roles. }\end{array}$ & Literature review & $\begin{array}{l}\text { An IBD specialist nurse competency framework would complement any future NMC } \\
\text { regulation of ANP roles and would demonstrate applied knowledge and skills, and the } \\
\text { increasing accountability and autonomous practice of IBD specialist nurses. }\end{array}$ \\
\hline $\begin{array}{l}\text { Taylor, Burch, } \\
\text { \& Black (2016). }\end{array}$ & $\begin{array}{l}6 \text { gastro nurses in London, } \\
\text { England }\end{array}$ & $\begin{array}{l}\text { Explore how a GI nursing } \\
\text { scholarship can develop } \\
\text { general nurses into } \\
\text { specialists. }\end{array}$ & $\begin{array}{l}\text { Descriptive design } \\
\text { with one-to-one } \\
\text { interviews of scholars } \\
\text { in a single UK centre. }\end{array}$ & $\begin{array}{l}\text { A funded academic scholarship with a blended academic learning approach combining } \\
\text { supernumerary GI clinical placements, supervision, funded study days and masterclasses } \\
\text { yields benefits including improved clinical skills, positive professional relationships, } \\
\text { heightened motivation, and greater opportunities to network and delivery of EBP. }\end{array}$ \\
\hline
\end{tabular}

Table 3. 


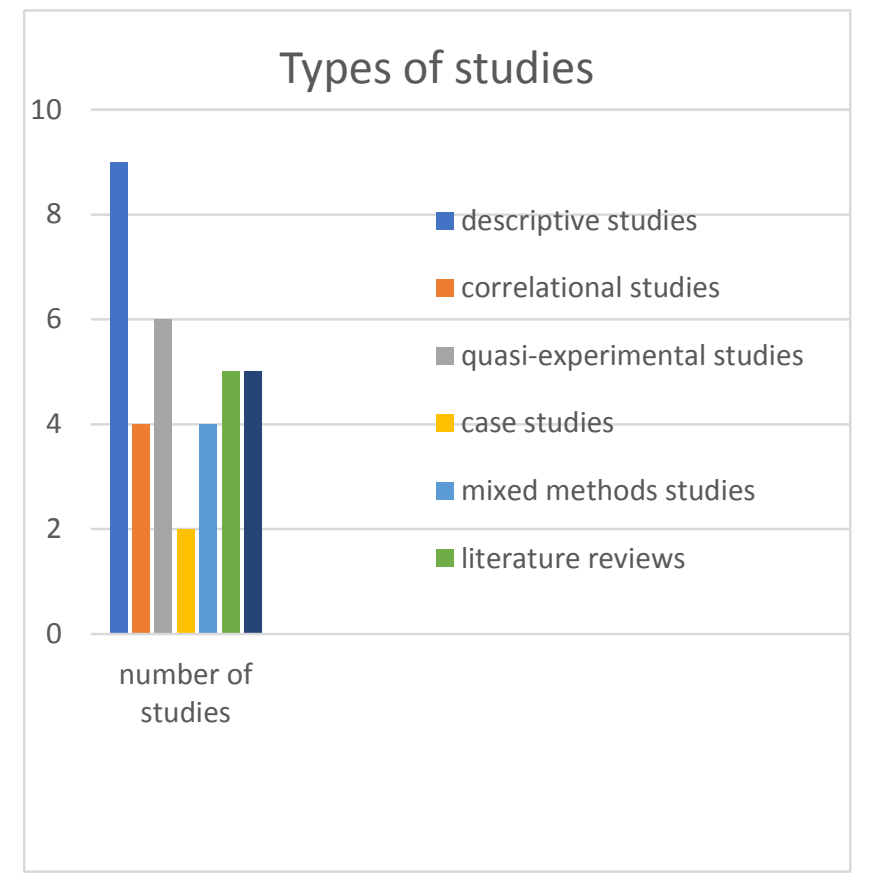

